\title{
Experimental detection of the actinospores of Myxobolus pseudodispar (Myxosporea: Myxobolidae) in oligochaete alternate hosts
}

\author{
Cs. Székely*, K. Molnár, E. Eszterbauer, F. Baska \\ Veterinary Medical Research Institute, Hungarian Academy of Sciences, PO Box 18, 1581 Budapest, Hungary
}

\begin{abstract}
The development of Myxobolus pseudodispar Gorbunova, 1936, an intracellular myxosporean muscle parasite of the roach Rutilus rutilus L., was studied in experimentally infected oligochaetes. In one experiment, uninfected Tubifex tubifex Muller and Limnodrilus hoffmeisteri (Claparéde) were exposed to mature spores of $M$. pseudodispar. Triactinomyxon spores developed both in $T$. tubifex and $L$. hoffmeisteri specimens. Triactinospores were first released from the oligochaetes $76 \mathrm{~d}$ after initial exposure. At that time, pansporocysts containing 8 triactinospores were located in the gut epithelium of experimentally infected oligochaetes, but free actinosporean stages were also found in their gut lumen. Each triactinospore had 3 pyriform polar capsules and an elongated cylindrical sporoplasm with 8 secondary cells. The spore body joined the 3 caudal projections with a relatively long style. One of the 3 caudal projections was shorter than the other two. The total length of the triactinospore was on average $206.5 \mu \mathrm{m}$.
\end{abstract}

KEY WORDS: Myxobolus pseudodispar $\cdot$ Myxosporea $\cdot$ Rutilus rutilus $\cdot$ Development $\cdot$ Triactinomyxon stage $\cdot$ Tubifex tubifex $\cdot$ Limnodrilus hoffmeisteri

\section{INTRODUCTION}

Myxobolus pseudodispar, a species described by Gorbunova (1936), is a myxosporean commonly occurring in the skeletal muscles of the roach Rutilus rutilus L. in Hungarian lakes, rivers and ponds (Baska 1986). Some aspects of its location and intrapiscine development were also studied by Baska (1986). Nothing was known, however, about its extrapiscine developmental stage.

The extrapiscine phase of a myxosporean was first studied by Wolf \& Markiw (1984), who revealed that the extrapiscine development of Myxobolus cerebralis Hofer took place in an oligochaete alternate host (Tubifex tubifex Müller). Following that pioneering work, several other papers were published to support its finding. These papers (El-Matbouli \& Hoffmann 1989, 1993, Ruidisch et al. 1991, Styer et al. 1991, ElMatbouli et al. 1992, Grossheider \& Körting 1992, Benajiba \& Marques 1993, Kent et al. 1993, Yokoyama

•E-mail: szekely@novell.vmri.hu et al. 1993, 1995, Uspenskaya 1995, Trouillier et al 1996. Yokoyama 1997) revealed that in each case various Oligochaeta spp. or Polychaeta sp. (Bartholomew et al. 1997) acted as alternate hosts in the development of various myxosporean species.

Recently the life cycles of 7 species from the genera Myxobolus, Thelohanellus and Sphaerospora have also been experimentally studied in our laboratory (ElMansy \& Molnár 1997a,b, El-Mansy et al. 1998a, Székely et al. 1998, Molnár et al. 1999a,b).

The work presented in this paper is part of continuing experimental life cycle studies conducted on the most common myxosporeans of Hungarian fishes. In the experiments reported here, the development of Myxobolus pseudodispar was followed in Tubifex tubifex and Limnodrilus hoffmeisteri alternate hosts.

\section{MATERIALS AND METHODS}

Myxospores of Myxobolus pseudodispar were collected from mature muscle cysts of 2 to $5 \mathrm{yr}$ old roach Rutilus rutilus specimens seined in Lake Balaton, Hun- 
gary. Pieces of the muscle were cut, compressed between 2 glass plates, and examined for the presence of myxosporean plasmodia. Plasmodia located intracellularly within muscle cells were separated and opened with a needle under a stereomicroscope. Mature spores obtained from plasmodia were identified and counted. A total of 190000 spores of M. pseudodispar were collected.

Oligochaetes Tubifex tubifex Müller and Limnodrilus hoffmeisteri (Claparéde), identified according to Brinkhurst (1963), were collected from the outlet of a duck farm in Szarvas, Hungary, where no fishes live. This parasite-free oligochaete stock containing members of the 2 species in about the same number was transferred to sterilised mud, and propagated in the laboratory in aerated aquaria. The worms were fed on some drops of granulated fish food.

The experiment started on 4 September 1998, when 100 specimens each of Tubifex tubifex and Limnodrilus hoffmeisteri were placed into a small plastic cup of $500 \mathrm{ml}$ volume, to which spores of Myxobolus pseudodispar were added. The calculated spore count per oligochaete was a total of 1000 . The temperature of the room during the experiment varied between 20 and $23^{\circ} \mathrm{C}$. All dishes were permanently aerated and regularly supplied with fresh water to prevent evaporation and to refresh the water for the oligochaetes. Starting from $42 \mathrm{~d}$ post-exposure (p.e.), water from the dishes was filtered weekly through a fine mesh of $21 \mu \mathrm{m}$ pore size. The filtrates were taken up in a drop of water and examined for the presence of actinospores. On Day 76 p.e. 150 oligochaetes were placed into $2 \mathrm{ml}$ cell-well plates as described by Yokoyama et al. (1991), and after $1 \mathrm{~d}$ of incubation they were examined for the release of actinospores under a stereomicroscope. Triactinospores released by the oligochaetes were examined under a coverslip. They were recorded on videotapes and digitized pictures were taken with the help of the IMAGO ${ }^{10}$ program as described by Székely (1997). Photographs were taken, drawings made and measurements of 47 actinospores recorded. In the description, all measurements are given in $\mu \mathrm{m}$. The actinosporean stage of $M$. pseudodispar was described using the terminology of Janiszewska (1957) as modified by Lom et al. (1997). After the first release of actinospores live $T$. tubifex and $L$. hoffmeisteri specimens were also examined for actinosporean stages under a compound microscope. After finding the first released triactinospores 2 infected $T$. tubifex and $1 \mathrm{~L}$. hoffmeisteri specimen were fixed in $5 \%$ glutaraldehyde for $1.5 \mathrm{~h}$ and post-fixed in $2 \%$ osmium tetroxide for $2 \mathrm{~h}$, washed several times with cacodylate buffer, dehydrated and embedded in Durcupan ACM resin. Semithin sections $(0.5$ to $1 \mu \mathrm{m})$ were made and stained with $0.1 \%$ toluidine blue solution.

\section{RESULTS}

\section{Light microscopy}

Actinospores of Myxobolus pseudodispar were released from both Tubifex tubifex and Limnodrilus hoffmeisteri, but no infection was found in the control tanks of the same oligochaete species. Of 150 specimens examined in cell-well plates, $4 T$. tubifex (5.3\%)

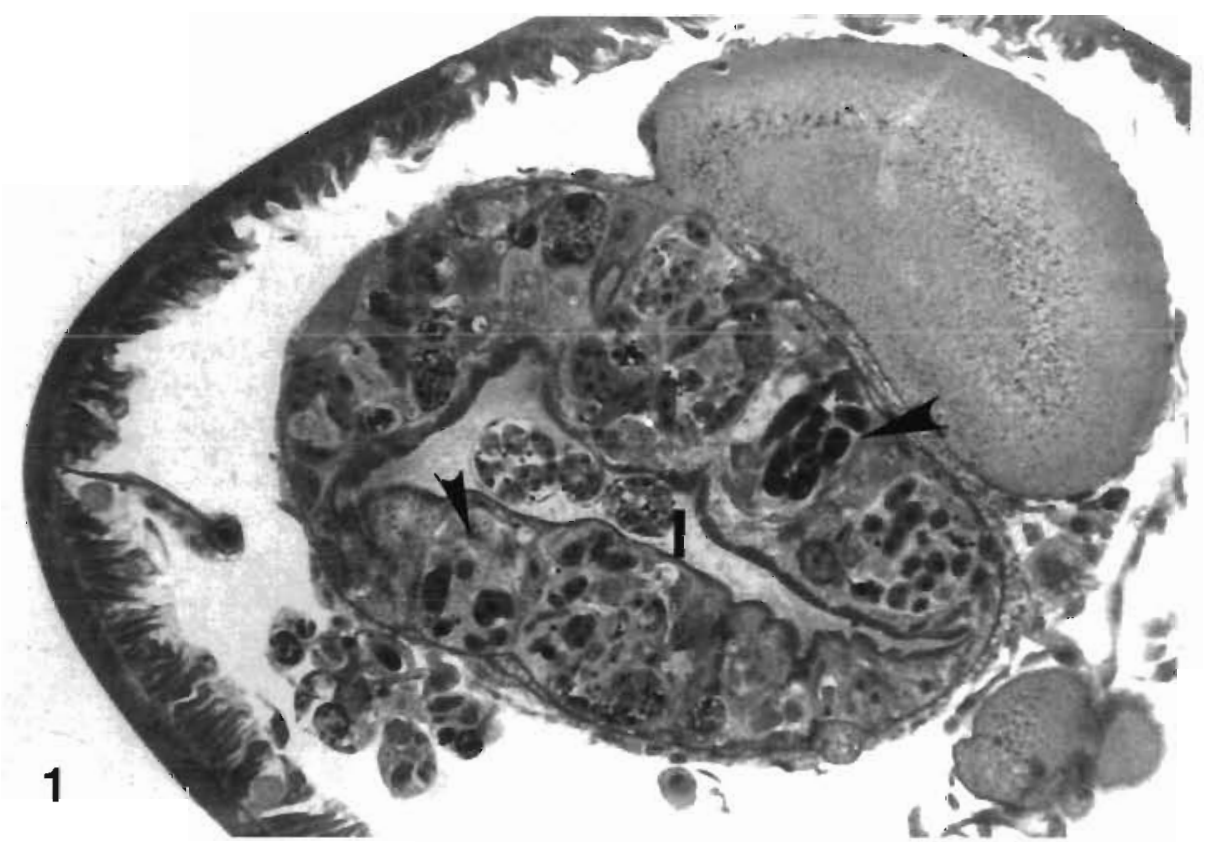

Fig. 1. Cross-section of Tubifex tubifex infected by Myxobolus pseudodispar. The intestine of the oligochaete is heavily infected with pansporocysts (arrowheads) located in the epithelium. Some released pansporocysts are found also in the intestinal lumen (l). Semithin section. $\times 250$ 
Fig. 2. Cross-section of Tubifex tubifex infected by Myxobolus pseudodispar. Enlarged part of Fig. 1 A spansporocyst containing 8 actinospores is located in the gut epithelium. Inside the pansporocyst sporoplasm, polar capsules (arrowhead) and folded membranes of the caudal processes $(m)$ of triactinospores are seen. Semithin section. $\times 2000$

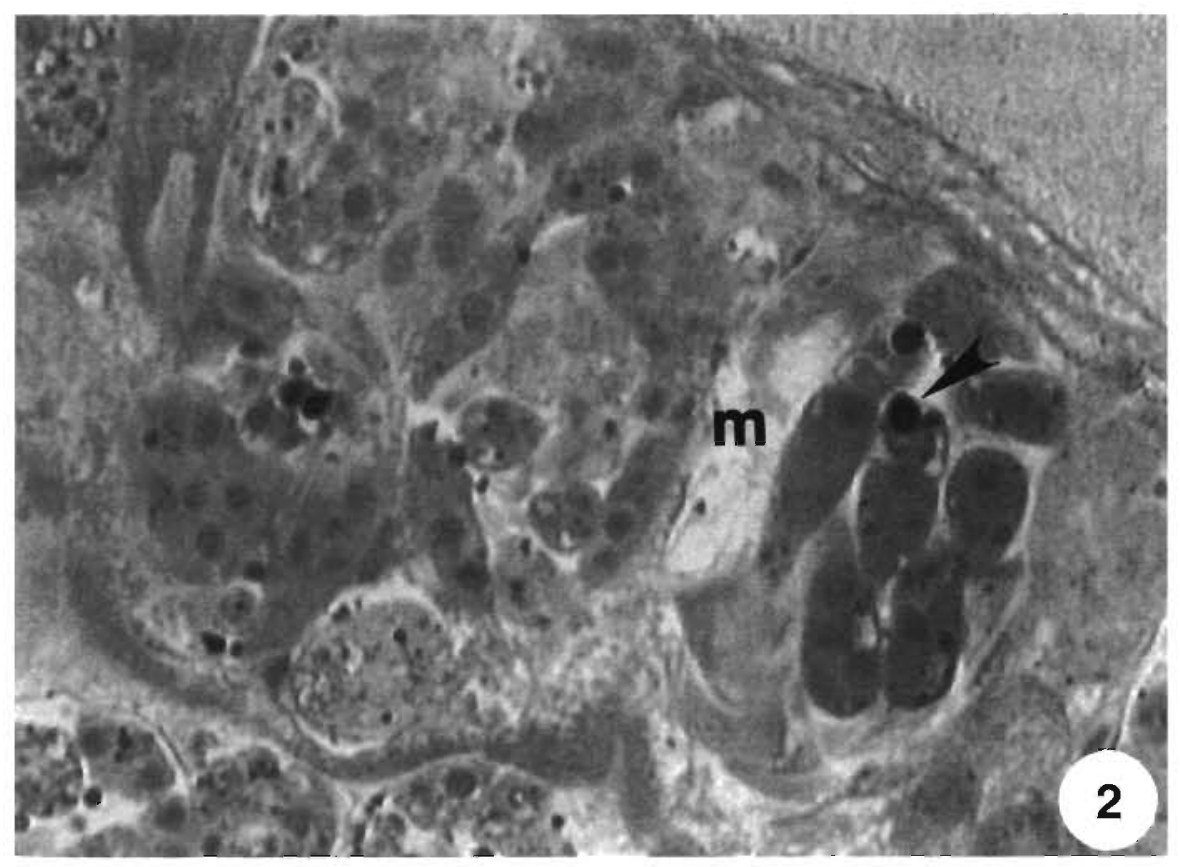

and 2 L. hoffmeisteri $(2.7 \%)$ proved to be infected. During the experiment, only triactinomyxon-type actinospores were obtained from all infected worms. The release of triactinospores lasted for about $30 \mathrm{~d}$. In infected live oligochaete specimens placed under a coverslip, pansporocysts in the gut epithelium and free spores in the gut lumen of the worms were easily seen under a compound microscope. No infection was found in the control oligochaete stock examined in the same numbers.

\section{Histology}

Pansporocysts of Myxobolus pseudodispar were mostly found in the gut epithelium, but pansporocysts and free spores released into the intestinal lumen through the damaged gut epithelium were also seen in semi-thin sections (Fig. 1). Eight triactinospores could be counted in a pansporocyst. In horizontally sectioned triactinospores the spore body with the sporoplasm and the dark-stained polar capsules could also be recognised (Fig. 2) Inside the sporoplasm large, round secondary cells were distinguishable. The free part of the spore body inside the pansporocyst was filled with the folded styles and caudal processes of the actinospores, which could easily be differentiated from the spore body by their pale colour.

Description of triactinospores. Triactinospores (Table 1, Figs. $3 \& 4$ ) released from the tubificid body and floating in the water were characterised by 3 pyriform polar capsules, a sporoplasm, a style and 3 caudal processes (Fig. 4). Polar capsules, pyriform in shape, were $5.1(4-6) \mu \mathrm{m}$ in length and $3 \mu \mathrm{m}$ in width. The cylindrical sporoplasm, $45(42-48) \mu \mathrm{m}$ long and 15.8 $(12-18) \mu \mathrm{m}$ wide, contained 8 spherical secondary cells $7.6(6.4-8) \mu \mathrm{m}$ in diameter (Fig. 3 inset). The style was relatively long, $157.3(145-173) \mu \mathrm{m}$ in length. Its width measured $15.8(12.8-18) \mu \mathrm{m}$ at the middle. Caudal processes were unequal in length, one of them being shorter. They were slightly bent, tapering toward the end and terminating in a sharply pointed end. The length of the 2 longer caudal processes was 196 (190-204) $\mu \mathrm{m}$, that of the shorter one 127.2 (104-144) $\mu \mathrm{m}$. Their width at the middle was $13.6(12-16) \mu \mathrm{m}$.

Table 1. Myxobolus pseudodispar. Measurements of the triactinospores (on the basis of 47 triactinospores) in $\mu \mathrm{m}$

\begin{tabular}{|llccc|}
\hline Measure & & Mean \pm SD & Minimum & Maximum \\
\hline Total length & & $206.5 \pm 15.6$ & 179.2 & 244 \\
Polar capsules & Length & $5.1 \pm 0.5$ & 4 & 6 \\
& Width & $3.0 \pm 0.0$ & 3 & 3 \\
Sporoplasm & Length & $45.0 \pm 2.2$ & 42 & 48 \\
& Width & $15.8 \pm 1.1$ & 12.8 & 18 \\
Spore body & Length & $50.4 \pm 2.4$ & 47 & 53 \\
Style & Width & $15.8 \pm 1.1$ & 12.8 & 18 \\
& Length & $157.3 \pm 14.8$ & 145 & 173 \\
Caudal processes & Width & $15.8 \pm 1.1$ & 12.8 & 18 \\
Longer & Length & $196.6 \pm 5.7$ & 190 & 204 \\
\multirow{2}{*}{ Shorter } & Width & $13.6 \pm 1.7$ & 12 & 16 \\
& Length & $127.2 \pm 14.8$ & 104 & 144 \\
\hline
\end{tabular}


Fig. 3. Myxobolus pseudodispar. Triactinospores floating in the water. $\times 500$. Inset: Spore body of the triactinospore with sporoplasm containing 8 sporoplasm cells and with polar capsules at the apical end. $\times 1200$

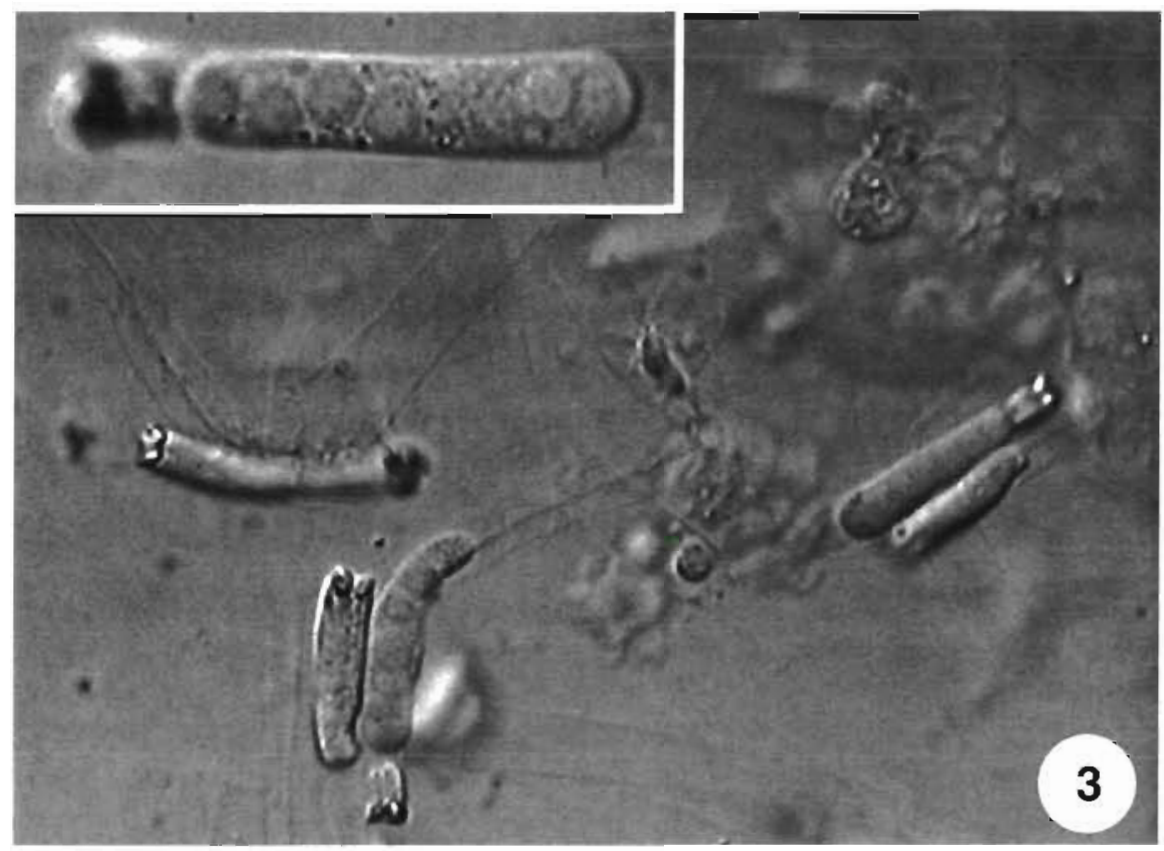

The length from the apical point of polar capsules to the end of sporoplasm (spore body) measured 50.4 (47-53) $\mu \mathrm{m}$. The total length from the polar capsules to the end of style (spore body with style) measured 206.5 (179-244) $\mu \mathrm{m}$.

\section{Differential diagnosis}

Both the myxospores and the actinospores of Myxobolus pseudodispar can readily be differentiated from those of other species by their asymmetric forms. The triactinomyxon stages of this species resemble other known triactinomyxospores of myxosporean spe-

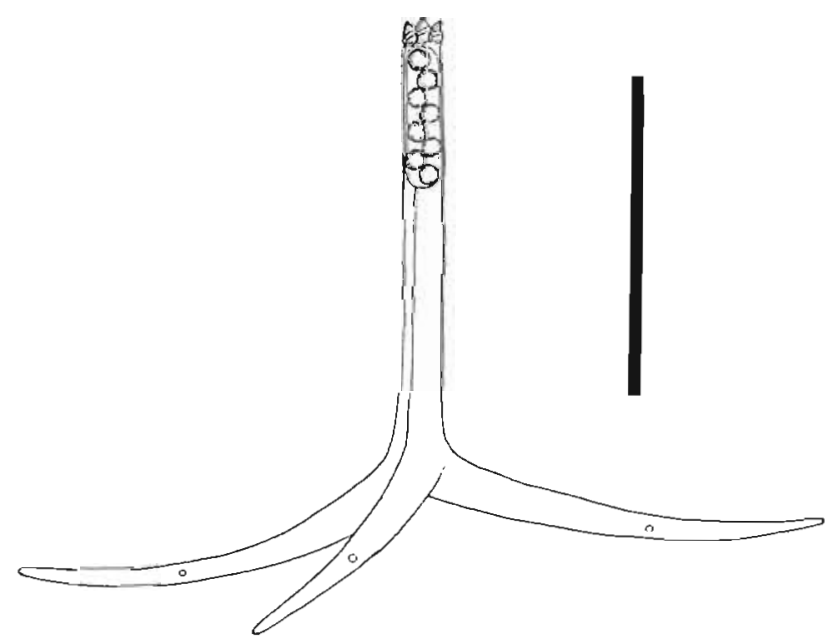

Fig. 4. Schematic drawing of the triactinospore of Myxobolus pseudodispar. $\mathrm{Bar}=100 \mu \mathrm{m}$ cies. However, they are distinguishable by the low number of secondary cells in the sporoplasm and by the shorter size of 1 of the caudal processes. The sporoplasm of this species has only 8 large sporoplasm cells and the third caudal process measures only two-thirds of the 2 others.

The triactinomyxons obtained in this experiment are probably identical to one of the triactinomyxon types (T2) detected by El-Mansy et al. (1998b) during a survey of actinospore infection of oligochaetes in a fish farm near Budapest.

\section{DISCUSSION}

The species Myxobolus pseudodispar is a rather common parasite of the roach in Hungary (Molnár 1979, Baska 1986, Székely \& Molnár 1996-1997). The validity of the species was questioned by Lom \& Dyková (1992), who regarded it as a synonym of $M$. cyprini. In the typical fish hosts (Cyprinus carpio and Rutilus rutilus) clear differences exist in the spore morphology (Molnár \& Kovács-Gayer 1985, Baska 1986), which supports the opinion represented by Gorbunova (1936) and Donec \& Shulman (1984); therefore, we regard $M$. pseudodispar as a valid species. In spite of its common occurrence, little is known about its pathogenicity. No studies have been done on the intraoligochaete development of this species. Data obtained in this study show that the intraoligochaete development of this parasite follows the same pattern as described by Wolf \& Markiw (1984) for $M$. cerebralis. In the present experiments the development of $M$. 
pseudodispar was successfully completed in both Tubifex tubifex and Limnodrilus hoffmeisteri, in which triactinomyxon-type spores developed. In their shape and size the spores resembled most of the triactinospores known from experimental studies on Myxobolus species $(M$. cerebralis, $M$. cotti, $M$. carassii, $M$. drjagini, $M$. portucalensis, $M$. hungaricus), but due to the low number of secondary cells in the sporoplasm and by the shorter length of one of the caudal processes they distinctly differed from the known triactinospores.

According to El-Matbouli et al. (1992), the intraoligochaete development of Myxobolus cerebralis, $M$. cotti and $M$. carassii took 80 to $120 \mathrm{~d}$, while for $M$. drjagini, $M$. hungaricus and $M$. portucalensis ElMansy \& Molnár (1997a,b) and El-Mansy et al. (1998a) reported development times of 91,102 and $160 \mathrm{~d}$, respectively. The patent period of $M$. portucalensis was somewhat shorter than that of the above-listed species.

The prevalence of infection $5.3 \%$ in Tubifex tubifex and $2.7 \%$ in Limnodrilus hoffmeisteri) proved to be relatively low compared to the high levels observed in previous experiments on Myxobolus drjagini, $M$. portucalensis, $M$. hungaricus and $M$. dispar (El-Mansy \& Molnár 1997a,b, El-Mansy et al. 1998a, Molnár et al. 1999a) in our laboratory. From a single experiment it is impossible to draw conclusions as to whether the alternate hosts, the myxospores or some other factors are responsible for this low prevalence.

Histological studies prove that Myxobolus pseudodispar develops in the gut epithelium of the oligochaete alternate host, from where its pansporocysts and spores are released into the lumen and subsequently excreted with the faeces.

Up to now, the intraoligochaete life cycle of about 20 species has been elucidated. However, a technique enabling consistently successful laboratory infection is known only in the case of Myxobolus cerebralis. The species $M$. pseudodispar is not ideal for use in experiments, as its relatively small, intracellular plasmodia can be collected and identified only with great difficulty. Reinfection of the fish host with actinospores is also difficult to achieve, as roaches reared infectionfree are not yet available. At the same time, the collected myxospores and the obtained actinospores provide excellent material for expanding the molecular biological studies that have already been done on other species (Andree et al. 1999).

Acknowledgements. The study was supported by the Hungarian Scientific Research Fund (OTKA, projects No. T 020044 and $T$ 029200). The authors thank Ms Zsuzsa Kis for her help in collecting and culturing tubificids, and are grateful to the Balaton Fisheries Co. for providing fish.

\section{LITERATURE CITED}

Andree KB, Székely Cs, Molnár K, Gresoviac SJ, Hedrick RP (1999) Relationships among members of the genus Myxobolus (Myxozoa: Bivalvidae) based on small subunit ribosomal RNA sequences. J Parasitol 85:68-74

Bartholomew JL, Whipple MJ, Stevens DG, Fryer JL (1997) The life cycle of Ceratomyxa shasta, a myxosporean parasite of salmonids, requires a freshwater polychaete as an alternate host. J Parasitol 83:859-868

Baska F (1986) Histological studies on the development of Myxobolus pseudodispar Gorbunova, 1936 in the roach (Rutilus rutilus). Acta Vet Hung 35:251-257

Benajiba MH, Marques A. (1993) The alternation of actinomyxidian and myxosporidian sporal forms in the development of Myxidium giardi (parasite of Anguilla anguilla) through oligochaetes. Bull Eur Assoc Fish Pathol 13: 100-103

Brinkhurst RO (1963) A guide for the identification of British aquatic Oligochaeta. Freshw Biol Assoc Sci Pub 22:1-55

Donec S, Shulman SS (1984) Parasitic protozoa. Phylum Cnidosporidia. In: Bauer ON (ed) Key to determination of parasites of freshwater fishes of the USSR, Vol I. Publ House Nauka, Leningrad, p 88-251 (in Russian)

El-Mansy A, Molnár K (1997a) Extrapiscine development of Myxobolus drjagini Achmerov, 1954 (Myxosporea: Myxobolidae) in oligochaete alternative hosts. Acta Vet Hung 45:427-438

El-Mansy A, Molnár K (1997b) Development of Myxobolus hungaricus Jaczó, 1940 (Myxosporea: Myxobolidae) in oligochaete alternate hosts. Dis Aquat Org 31:227-232

El-Mansy A, Molnár K, Székely Cs (1998a) Development of Myxobolus portucalensis Saraiva \& Molnár, 1990 (Myxosporea: Myxobolidae) in the oligochaete Tubifex tubifex (Müller). Syst Parasitol 41:95-103

El-Mansy A, Székely Cs, Molnár K (1998b) Studies on the occurrence of actinosporean stages of fish myxosporeans in a fish farm of Hungary, with the description of triactinomyxon, raabeia, aurantiactinomyxon and neoactinomyxon types. Acta Vet Hung 46:259-284

El-Matbouli M, Hoffmann RW (1989) Experimental transmission of two Myxobolus spp. developing by sporogeny via tubificid worms. Parasitol Res 75:461-464

El-Matbouli M, Hoffmann RW (1993) Myxobolus carassii Klokacheva, 1914 also requires an aquatic oligochaete, Tubifex tubifex as intermediate host in its life cycle. Bull Eur Assoc Fish Pathol 13:189-192

El-Matbouli M, Fischer-Scherl T, Hoffmann RW (1992) Transmission of Hoferellus carassui Achmerov, 1960 to goldfish Carassius auratus via an aquatic oligochaete. Bull Eur Assoc Fish Pathol 12:54-56

Gorbunova $M$ (1936) Changes in the parasitic fauna of pike and roach according to their age. Uchenye Zapiski Leningradskogo Ordena Lenina Gosudarstvennogo Universiteta, No. 7. (Biol Ser) Fasc 3, Problems of Economical Parasitology, Leningrad, p 5-30 (in Russian)

Grossheider G, Körting W (1992) First evidence that Hoferellus cyprini (Doflein, 1898) is transmitted by Nais sp. Bull Eur Assoc Fish Pathol 12:17-20

Janiszewska J (1957) Actinomyxidia II. New systematics, sexual cycles, description of new genera and species. Zool Polon 8:3-34

Kent ML, Whitaker DJ, Margolis L (1993) Transmission of Myxobolus arcticus Pugachev and Khokhlov, 1979, a myxosporean parasite of Pacific salmon, via a triactinomyxon from the aquatic oligochaete Stylodrilus heringianus (Lumbriculidae). Can J Zool 71:1207-1211 
Lom J, Dykova I (1992) Protozoan parasites of fishes. In: Series of developments in aquaculture and fisheries science, Vol 26. Elsevier, Amsterdam, p 159-237

Lom J, McGeorge J, Feist SW, Morris D, Adams A (1997) Guidelines for the uniform characterisation of the actinosporean stages of parasites of the phylum Myxozoa. Dis Aquat Org 30:1-9

Molnár K (1979) Protozoan parasites of fish species indigenous in Hungary. Parasit Hung 12:5-8

Molnár K. Kovács-Gayer É (1985) The pathogenicity and development within the host fish of Myxobolus cyprini Doflein, 1898. Parasitology 90:549-555

Molnấr K, El-Mansy A, Székely Cs, Baska F (1999a) Development of Myxobolus dispar Thelohan, 1895 (Myxosporea: Myxobolidae) in an oligochaete alternate host. Tubifex tubifex (Müller). Folia Parasitol 46:15-21

Molnár K, El-Mansy A, Székely Cs, Baska F (1999b) Development of Sphaerospora renicola Dykova and Lom, 1982 (Myxosporea: Sphaerosporidae) in oligochaete alternate hosts. J Fish Dis 22:1-11

Ruidisch S, El-Matbouli M, Hoffmann RW (1991) The role of tubificid worms as an intermediate host in the life cycle of Myxobolus pavlovskii (Akhmerov, 1954). Parasitol Res 7:663-667

Styer EL, Harrison L, Burtle GJ (1991) Experimental production of proliferative gill disease in channel catfish exposed to a myxozoan-infected oligochaete, Dero digitata. J Aquat Anim Health 3:288-291

Székely Cs (1997) Possible applications of video technology and digital image processing in fish parasitology: morphological examination of the groups Apicomplexa and Myxosporea-Actinosporea by video technology. Bull Eur Assoc Fish Pathol 17:81-82

Székely Cs, Molnár K (1996-1997) Preliminary survey of the parasite fauna of some important fish species in the Upper Reser-

Editorial responsibility: Wolfgang Korting,

Hannover, Germany voir of the Kis-Balaton System. Parasit Hung 29-30:45-54 Székely Cs, El-Mansy A, Molnár K, Baska F (1998) Development of Thelohanellus hovorkai and Thelohanellus nikolskii (Myxosporea: Myxozoa) in oligochaete altemate hosts. Fish Pathol 33:107-114

Trouillier A, El-Matbouli M, Hoffmann R (1996) A new look at the life-cycle of Hoferellus carassii in the goldfish (Carassius auratus auratus) and its relation to 'kidney enlargement disease' (KED). Folia Parasitol 43:173-187

Uspenskaya AV (1995) Alternation of actinosporean and myxosporean phases in the life cycle of Zschokella nova (Myxozoal. J Euk Microbiol 42:665-668

Wolf K, Markiw ME (1984) Biology contravenes taxonomy in the myxozoa: new discoveries show alternation of invertebrate and vertebrate hosts. Science 225:1449-1452

Yokoyama H (1997) Transmission of Thelohanellus hovorkai Achmerov, 1960 (Myxosporea: Myxozoa) to common carp Cyprinus carpio through the alternate oligochaete host. Syst Parasitol 36:79-84

Yokoyama H, Ogawa K, Wakabayashi H (1991) A new collection method of actinosporeans - a probable infective stage of myxosporeans to fishes-from tubificids and experimental infection of goldfish with the actinosporean, Raabeia sp. Fish Pathol 26:133-138

Yokoyama $H$, Ogawa K, Wakabayashi $H$ (1993) Involvement of Branchiura sowerbyi (Oligochaeta: Annelida) in the transmission of Hoferellus carassii (Myxosporea: Myxozoa), the causative agent of kidney enlargement disease (KED) of goldfish Carassius auratus. Fish Pathol 28: $135-139$

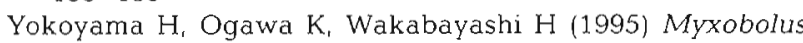
cultus n. sp. (Myxosporea: Myxobolidae) in the goldfish Carassius auratus transformed from the actinosporean stage in the oligochaete Branchiura sowerbyi. J Parasitol $81: 446-451$

Submitted: May 17, 1999; Accepted: September 3, 1999

Proofs received from author(s): November 16, 1999 